\title{
Conservation habitat treatment from thread of extinction in turtle conservation and education center (tcec), bali
}

\begin{abstract}
Turtle is one of the fauna protected because of its endangered population. These marine reptiles are able to migrate in great distances along the Indian Ocean, Pacific Ocean, and Southeast Asian regions. In the world there are 7 types of turtles and 6 of them are found in Indonesia. Conservation is one activity that is expected to prevent the extinction of turtle habitat due to natural and human predators.

The research was conducted from 4-24 August 2014 and held at Turtle Conservation and Education Center (TCEC), South Denpasar, Bali. This study aims to determine the conservation techniques and the success rate of hatching of sea turtle eggs in TCEC, Bali. The method used in this research is the method of interview, observation or direct observation conducted in the field, and semi-natural semi-temperature measurement method. Temperature measurements were performed to determine the sex of the hatching hatchlings.

The results showed that the turtle breeding location is in a less strategic area because it is too far from the sea water so that the temperature and humidity cannot be stable. Water content is an important factor in embryonic growth and egg hatching. This will lead to a decrease in the percentage of turtle egg hatching. TCEC was established as a place for turtle conservation education, turtle conservation, and turtle providers for traditional ceremonies in Bali as well as reducing trade in meat, shell or sea turtle eggs.
\end{abstract}

Keywords: Preservation, Turtle, TCEC Bali
Volume 6 Issue 3 - 2017

\author{
Edi Wibowo, Raden Ario \\ Faculty of Fisheries and Marine Sciences, Diponegoro University \\ Tembalang Campus, Indonesia
}

Correspondence: Edi Wibowo, Faculty of Fisheries and Marine Sciences, Diponegoro University Tembalang Campus, Indonesia, Tel 024-7474698, Email ediwibowo1960@gmail.com

Received:September 13,2017| Published: September 18, 2017

\section{Introduction}

Indonesia is the largest archipelagic country in the world with more than 17,500 islands along the equator and over 360 million hectares of marine areas. Spreads between 20o isothermal LU/LS is a good location for coral reef growth, seaweed and biodiversity including sea turtles. ${ }^{1}$

In the world there are 7 types of turtles and 6 of them are found in Indonesia. The species of turtle in Indonesia are Green Turtle (Chelonia mydas), Hawksbill (Eretmochelys imbricata), Lekang Turtle (Lepidochelys olivacea), Leatherback Turtle (Dermochelys coriacea), Turtle (Natator depressus) and Turtle Turtle (Caretta caretta).

Turtles have experienced a decline in the number of populations in this last even period some species are threatened with extinction. In nature, newly hatched turtles face death threats from animals such as crabs, birds and other reptiles such as monitor lizards. The greatest threat to turtles in Indonesia, as well as around the world, is human. Excessive coastal development has reduced the habitat of turtles to nesting. Catching turtles for eggs, meat, leather, and shells has reduced turtle populations. All turtles according to Sukresno. ${ }^{2}$ have been listed in Appendix I of CITIES (Conventions on International Trade of Endangered Species). This Convention prohibits all international trade in all products derived from turtles, whether in the form of eggs, meat, or shells.

Based on the legislation type of leatherback turtle protected by Minister of Agriculture Decree No.327 / Kpts / Um / 5/1978; Turtle and Lekang Turtles are protected under the Decree of the Minister of Agriculture No.716 / Kpts / Um / 10/1980; Hawksbill turtles and turtles are protected by Ministry of Forestry Decree No. 882 / Kpts-II / 1992, and Green Turtles belonging to 6 species of protected turtles based on Government Regulation No.7 / 1999 on the preservation of plants and animals.

Conservation is one of the activities that is expected to prevent the loss of sea turtle habitat, preventing the use of turtles for commercial purposes such as the sale of eggs, meat, and shells and can be a means of sharing knowledge or education to the public widely about the importance of turtle conservation in order to protect turtle habitat in Indonesia to avoid extinction.

The purpose of this research is to know all kinds of activities on conservation in TCEC, and disseminate information related to the protection and preservation of sea turtles to the public at large.

While the benefits of this research is expected to provide information to the public and related agencies in implementing the management and protection of turtle habitat in the area of Turtle Conservation and Education Center (TCEC), Bali so that it can support the conservation of turtle habitat in Indonesia.

\section{Materials and methods}

The research was conducted in the period from August 4, 2014 to August 24, 2014 with observation location at Turtle Conservation and Education Center (TCEC), South Denpasar, Bali. The material used in this research is about the conservation of turtle in Turtle Conservation and Education Center (TCEC). Data collection is obtained from measurement of length, width, and coastal slope, humidity and humidity. 
Equipment used in this research are: research location map, GPS (Global Positioning System), coastal plant identification book, thermometer, rool meter, scaled stick, sample bag, digital camera, and stationery.

The method used in this research is descriptive survey method. According to Nasir. ${ }^{3}$ this method is to create a systematic, factual, and accurate description of the facts, properties and relationships between environmental factors or learned phenomena. Data collection was done by interview, direct observation in the field, and semi semi-natural temperature measurement. Methods of interviews with related agency managers, observation or direct observation of activities undertaken in the field to determine what activities exist in the conservation area. Temperature measurements at semi-natural enlargement and nest ponds are conducted from day 4 to day 15 within the specified timeframe at 08.00 WITA. Temperature measurements using a thermometer inserted into a semi-natural nest and then recorded the measurement results. After that record the number of eggs in seminatural nest and record how many eggs that hatch or hatch failed.

\section{Results and discussion}

The number of ponds enlarged in TCEC amounted to 15 pounds of the same size. A total of 12 ponds contain the most Tukik Tukik in the pool to 6 and 7 is 350 hatchling. Swimming 1 to 4 filled Tukik with the least amount of 200 tail/pond. A total of 3 ponds filled with turtles with the largest number of sea turtles to 9 with 5 turtles, and most slightly on the 5 th pool with 2 turtles and more can be seen in Table 1 below.

Tabel I Number of Trowels and Turtles at the Magnification Pond at TCEC

\begin{tabular}{lll}
\hline $\begin{array}{l}\text { Pond } \\
\text { enlargement }\end{array}$ & $\begin{array}{l}\text { Number of } \\
\text { turtles (Tail) }\end{array}$ & $\begin{array}{l}\text { Number of } \\
\text { turtles (Parent) }\end{array}$ \\
\hline I & 200 & - \\
2 & 200 & - \\
3 & 200 & - \\
4 & 200 & - \\
5 & - & 2 \\
6 & 350 & - \\
7 & 350 & - \\
8 & 329 & - \\
9 & - & 5 \\
10 & - & 3 \\
II & 250 & - \\
I2 & 250 & - \\
13 & 250 & - \\
14 & 250 & - \\
15 & 250 & - \\
\hline
\end{tabular}

Conservation is a very important effort for the sustainability of sea turtles themselves from the threat of extinction caused by various threat factors such as poaching of eggs and shells from sea turtles, as well as from natural predators such as ants, monitor lizards, and others. In TCEC there are 3 species of turtle Green Turtle (Chelonia mydas), Hawksbill (Eretmochelys imbricata), and Lekang Turtle (Lepidochelys olivacea). While the species of hatchlings in the TCEC Lekang species (Lepidochelys olivacea).

Priyono. ${ }^{4}$ states that the turtle size structure is grouped into four categories: (1) Young Tukik: new born / hatching and still looks umbilical cord, until the first week. (2) Tukik: the rest of the umbilical cord is gone and carapace length $\pm 40 \mathrm{~cm}$. (3) Young: uncomplicated tamer (long carapace about $40-80 \mathrm{~cm}$ ). (4) Adult: mature sex or mature sex, carapace length greater than $80 \mathrm{~cm}$ (minimum female size about $80 \mathrm{~cm}$ ).

Turtles are all-consuming animals (Omnivores). Each type of turtle has a specific food. Turtles have a special shape of the mouth and beak to help get their food. Hawksbill Turtle has a tapered head and beak shape to make it easier to find food on coral reefs. Turtle Lekang is one of the carnivorous turtles, and has a strong and strong beak to prey on fish, jellyfish, squid, starfish, clams, kima, crab and shrimp. While Rebel. ${ }^{5}$ states that Green Turtle is the only type of turtle that is known to be herbivorous. Predators of algae and seagrasses. The results of interviews with TCEC managers, known to the existence of turtles are often found in Serangan Island, South Denpasar and Bali. Serangan Island is the habitat of nesting turtle penyek itself. But over time many people began to consume meat or sea turtle eggs. Meat processed into satay sold freely. Even in traditional ceremonies in some areas of Bali using this sea turtle as a symbol of ceremony and killed. The island of Bali has received much criticism from people outside of Bali even abroad and the parties on behalf of animal protection extinction due to ceremonial acts in Bali that many use turtles. But for now it is rare for traditional ceremonies in Bali that use turtles, if there is to be limited the number of sea turtles used and the age of the turtle. This step is done in order to maintain the sustainability of sea turtles themselves.

The establishment of the Turtle Conservation and Education Center (TCEC) serves as a turtle conservation site, a semi-natural hatchery area of turtle eggs taken from its natural nest along the coast so that the eggs can hatch safely without being disturbed by predators or humans. In addition TCEC also as a place of turtle-hatching penyik Lekang which will be released into the sea if the age has been approximately 3 months.

This step is taken as a solution so that people do not take turtles directly from the sea in order to preserve the habitat of turtle habitat. The turtles provided for the one-year-old custom ceremony are more numerous and the numbers are also limited. TCEC is also used as a means of education and serve as a tourist spot for local and foreign tourists to know more closely about the turtles as well as expected awareness raising to preserve sea turtles from the threat of extinction. There is an activity called "Adopt a hatchling" where this activity is aimed at tourists who want to remove the hatchling into the sea from the beach. The contribution of money from tourists in the "adoption" activity is what is used as income to buy hatchlings, and others. The tourists (local and foreign) are also certified as volunteers from TCEC. TCEC cooperation with WWF Indonesia is under the auspices of Natural Resources Conservation Center (BKSDA) Denpasar, Bali.

The number of hatchlings and turtles at the TCEC enlargement pond (Table 1) amounted to 15 ponds, of which 12 ponds contained hatchlings and 3 ponds containing turtles. The highest number of hatchlings at the 6 th and 7 th pools were 350 hatchlings and ponds 1 to 4 filled with the fewest hatchlings of 200 hatchlings. The 3 ponds are filled with sea turtles with the largest number of turtles in the 9 th pool with 5 tails and at least 2 tails on the pond 5 . The previous individual data collection in 2013, according to Mr. Griye as field supervisor and TCEC manager known that the number of hatchlings and turtles in a pool of enlarged amounts less than in 2014. Data from the table above is the number of hatchlings and turtles are good for survival and reduce deaths due to the full pond by turtles and turtles. The main thing to consider in the maintenance of hatchlings is the circulation of water. Regular water circulation causes food waste and the secretion of the hull is reduced constantly. In addition, the skincausing microorganisms in the hatchlings are not easy to develop. ${ }^{6}$ 
The Maintenance System must meet the ecological requirements. In addition to the procurement of water circulation, the area of maintenance is also given special attention. It aims to provide widespread space for the hatchlings because the hatchling is an active moving animal. ${ }^{7}$ Water depth of maintenance media also contributes to the growth of hatchlings during maintenance. Stated in Nontji. ${ }^{8}$ that in his first days in the water, hatchling has not been able to dive because in his body is still undigested egg yolk. The presence of the egg yolk causes the body weight of the hatchling body to be low and can only swim on the surface.

The quality of water used for live hatchlings also requires special attention. Parameters that must be considered in maintaining water quality media include $\mathrm{pH}$, salinity and temperature and dissolved

Table 2 Birth and Death baby turtle data in TCEC oxygen (DO). Sea water has a relatively stable $\mathrm{pH}$ range due to its high buffering capacity. ${ }^{6}$ Salinity affects the biological activity in the osmoregulation process. Turtle is a poikilotermal animal, body temperature follows environmental temperature to some extent .9

Birth and dive death data in semi-natural nest and the measurement of temperature in semi-natural nest starting from day 4 to day 15 in the predicted timeframe at 08.00 WITA (Table 2). It is known how many hatchlings that can hatch and fail to hatch in a semi-natural nest and temperature measurement is done to determine the sex of the hatching hatchlings. On day 1 to 3, no data were collected. Eggs in each nest amounted to 100 grains with the measured temperature range from $28^{\circ} \mathrm{C}$ to $32^{\circ} \mathrm{C}$.

\begin{tabular}{llllll}
\hline Day & Date & Temperature of the nest ${ }^{\circ} \mathbf{C}$ & Number of eggs & Hatch & Failed to hatch \\
\hline 1 & $06 / 08 / 2014$ & - & - & - & - \\
2 & $07 / 08 / 2014$ & - & - & - & - \\
3 & $08 / 08 / 2014$ & - & - & - & - \\
4 & $09 / 08 / 2014$ & $30-31$ & 100 & 70 & 30 \\
5 & $10 / 08 / 2014$ & $28-31$ & 100 & 59 & 41 \\
6 & $11 / 08 / 2014$ & $31-32$ & 100 & 25 & 75 \\
7 & $12 / 08 / 2014$ & $30-31$ & - & - & - \\
8 & $13 / 08 / 2014$ & $30-31$ & 100 & 49 & 51 \\
9 & $14 / 08 / 2014$ & $30-31$ & 100 & 72 & 28 \\
10 & $15 / 08 / 2014$ & $29-30$ & - & - & - \\
11 & $16 / 08 / 2014$ & $29-30$ & - & - & - \\
12 & $17 / 08 / 2014$ & $29-30$ & 100 & 62 & 38 \\
13 & $18 / 08 / 2014$ & $28-31$ & 100 & 67 & 33 \\
14 & $19 / 08 / 2014$ & $30-31$ & 100 & 68 & 32 \\
15 & $20 / 08 / 2014$ & $30-31$ & - & - & - \\
\hline
\end{tabular}

Number of hatching eggs most obtained on the day to 9 that is 72 eggs and the number of eggs that failed to hatch most obtained on day 6 that is 75 eggs. Factors that affect the eggs can hatch with a large number or fail to hatch due to the influence of sand used, the change of sand used, and the depth of the semi-natural nest. On days $7,10,11$, and 15 no eggs were hatched or failed to hatch. According to Limpus. ${ }^{10}$ from hundreds of eggs issued by a female turtle, at most only a dozen turtles managed to get back to the sea and grow up. And that does not take into account the hunting factors by humans and natural predators such as crabs, birds and rats on the beach, as well as big fish so deeply it touches the deep waters.

Upon completion of the spawning period the parent will return to the sea, the turtle egg breeding period is about 45-60 days and the temperature in the nest will determine the gender of the hatch itself, so the lower the temperature within the nest, it will produce more male turtles and vice versa if the temperature of the nest is high then the hatchlings that are produced are mostly female. The newly hatched hatch will find its way beyond the nest surface for 3-7 days and then the hatchling will be out of the nest at night because of the cooler temperatures and the threat of very few predators and the hatchling going directly to the ocean. Upon reaching the sea, the hatchlings use a variety of guided clues (wave direction, current and magnetic field) for orientation to deeper offshore areas. The activities of hatchlings passing by the beach and swimming away are an attempt to record the clues needed to find their way home when they are about to mate, called the imprinting process. When the hatchling is already in the sea allegedly entering the area where the ocean currents meet, the hatchlings use floating seaweeds. Tukik rarely seen again until the carapnya reach the size of $20-40 \mathrm{~cm}$ with the age of about 5-10 years after hatching. Tukik usually hide around the coral reefs and seagrass (Marine Fisheries Service, 2009). At the time the grown-up dive goes back to the coastal feeding ranch and lives in the area until it is ready to spawn and then the turtle's life cycle begins again. The period of disappearance is referred to as the lost years (the lost years), which turned out to be a snorkeling and forage in the area of seaweed species Sargassum sp. Declared in the office of Marine Fisheries (2009) that of the 1000 tail diik that to the sea there is only one that will survive until adulthood. ${ }^{11-13}$

The conservation of turtles by TCEC has had a positive impact on the change of mindset of people in Serangan Island and other areas of Bali to develop turtle conservation efforts by setting up observation posts along the coast which are useful to observe if turtles are rising to the lay eggs and save their eggs from natural predators as well as humans who want to take it. Participating and disseminating the importance of turtle conservation efforts so that beaches in Bali can still be a place for the turtles to rise to the mainland and lay eggs and socialization conducted with school children and students and female students about what turtle conservation, the importance of efforts made preservation of turtle habitat is maintained by not disposing plastic waste into the sea because it can be consumed by turtles, do not eat turtle meat into dishes in luxury restaurants in Bali and reduce the turtle catching efforts in nature to be used as material in traditional ceremonies in Bali.

\section{Conclusion}

I. Turtle conservation at TCEC has activities such as hatching turtle eggs in semi-natural nests, enlarging hatchlings in enlarging ponds, adopting hatchlings for release into the sea, as well as for educational facilities. 
II. The conservation of turtles is now better than before because now people are aware not to sell turtle shells, do not hunt turtles in the wild anymore as material for traditional ceremonies, and do not consume sea turtle meat and eggs.

\section{Suggestions}

I. Information on marine turtle conservation should be disseminated so that all communities can know the benefits of sea turtle conservation itself.

II. Any form of trade concerning sea turtles, either meat or shells, shall be stopped and sea turtles shall be protected by special laws which shall keep this animal from becoming extinct.

\section{Acknowledgements}

None.

\section{Conflicts of interest}

None.

\section{References}

1. Limpus CJ, McLachlan N The conservation status of the leatherback turtle, Dermochelys coriacea, in Australia. In: R James (Ed.), Proc. Marine Turtle Conservation Workshop, Canberra, Australia, pp. 1996;68-72.

2. Sukresno SA Pemanfaatan Penyu Laut di Indonesia. Makalah Seminar Penelitian dan Pengelolaan Penyu di Indonesia, Jember-Indonesia. 1997
3. Nasir M Metode Penelitian. Ghalia. Jakarta, pp. 1988;1-14.

4. Priyono A Penyu dan kura-kura (ordo Chelonia). Jurusan Konservasi Sumberdaya Hutan Fakultas Kehutanan Institut Pertanian Bogor. Bogor, Indonesia. 1988

5. Rebel TP SeaTurtle and The Turtle Industry of The West Indies, Florida, and The Gulf of Mexico. University of Miamy Press. Coral Gables. USA, pp. 1974;134.

6. Naulita Y Telaah laju pertumbuhan tukik Penyu Hijau (Chelonia mydas) pada pemberian makan yang berbeda. Jurusan Managemen Sumberdaya Perikanan, Fakultas Perikanan IPB. 1990

7. Nuitja INS Biologi dan Ekologi Pelestarian Penyu Laut. IPB Press. Bogor, Indonesia. 1992

8. Nontji A Laut Nusantara. Cetakan Keempat. Djambatan. Jakarta, Indonesia. 2005

9. Jackson DC Respiration, in turtle prespective and research. In: M Harles \& H Morlock (Eds.), A Wiley Interscience Publication.USA. pp. 1979;165-191.

10. Limpus C J Notes Rates Growth, Marine Conservation Rates of Wild Turtles. Marine Turtles News Latter. Australia. 1970

11. Departemen Kehutanan Peraturan Pemerintah Republik Indonesia Nomor 7 tahun 1999 tentang Pemanfaatan Jenis Tumbuhan dan Satwa. Departemen Kehutanan Indonesia. Jakarta, Indonesia, pp. 1999;1-32.

12. Dinas Kelautan Perikanan Laut, Pesisir dan Pulau-pulau Kecil. Departemen Kelautan dan Perikanan, Jakarta. 2009

13. Yayasan Alam Lestari (YAL) Mengenal Penyu. Yayasan Alam Lestari dan Keidanren Nature Conservation Fund (KNCF) Jepang, Japan. 2000. 